\title{
Flora and vegetation of the Minusinsk town and its vicinity
}

\author{
Maria Larina, Olga Zyryanova* \\ Khakas State University named after N.F. Katanov, 90 Lenin St., 655000, Abakan, Russia
}

\begin{abstract}
The article demonstrates the results of studies about species composition of lichens, fungi, mosses and higher vascular plants found in the ribbon pine forests in the Minusinsk town and its vicinity. The article based on the original authors' herbaria. 62 basidial macromycetes, 80 lichens and 210 species of the higher vascular plants were found in the studied area. The plant communities and their dominant species were studied.
\end{abstract}

\section{Introduction}

The town of Minusinsk is an urban district, located in the southern part of the Krasnoyarsk Territory, in the center of the vast forest-steppe Minusinsk Hollow, on the right bank of the Yenisei River [1].

Every year the territory of the town of Minusinsk and its vicinity gets more and more exposed to anthropogenic influence. Forest communities serve as a recreation area for the residents, as well as a dumping ground. Surface fires are often happened in spring and summer. Meadow and steppe communities during the vegetation period are often serves as pastures and places for the wild medicinal plants gathering. These and other factors lead to the changes in the natural flora and vegetation. Therefore, it becomes necessary to study species composition of lichens, fungi, and higher vascular plants in the typical plant communities of the Minusinsk town and its vicinity.

\section{Material and methods}

Authors collected about 550 herbarium specimens of higher vascular plants, 180 lichens, and 60 mushrooms which were the base for the article. The collected herbarium materials were processed in the laboratories of Khakas State University named after N.F. Katanov with the use of binocular MBS-10, microscope "Biolan" and chemical reagents. Species were determined with the help of "Identification Guide to the Plants of the South of the Krasnoyarsk Territory" [2], "Flora of Siberia" [3], "Identification Guide to Lichens of the USSR" [4], "Identification Guide to Lichens of Russia" [5], "Nordic Lichen Flora" [6], "Flora of Fungi of Ukraine" [7, 8], "Identification Guide to Fungi of Russia" [9], «Funga Nordica» [10], «Farbatlas der Basidiomyceten Colour Atlas of Basidiomycetes» [11],

\footnotetext{
*Corresponding author: o a zyryanova@mail.ru
} 
"Floras of Agaric Mushrooms of the Southern Part of the Krasnoyarsk Territory [12], "Mushrooms of the USSR" [13], "Fungi. Identification Atlas" [14].

\section{Results and discussion}

Vegetation cover of Minusinsk town and its vicinity is represented by a variety of different plant communities. Due to the synanthropization and degradation of vegetation cover in urban areas, the urban vegetation is divided into cultivated (park and garden complexes, lawns) and natural (steppes, forests, and meadows) [15]. The main types of green plantings in the town are parks, squares, street greenery, and common lands, while the natural vegetation on the territory of the town is preserved fragmentary and weakly represented in the residential area. The natural plant communities are more often found in the vicinity of Minusinsk, where they occupy large areas. Natural vegetation is comprised of true meadows, less often rocky steppes, valley meadows, forests (pine, birch, mixed birch-pine) and coppices.

The fescue-koeleria low-bunch steppes occupy the southern slopes. The edificators of formation are Koeleria cristata (L.) Pers. and Festuca pseudovina Hack. ex Wiesb. Abundant species include Poa stepposa L., Agropiron cristatum (L.) Beauv. and Cleistogenes squarrosa (Trin.) Keng.

Among the constant species of low-bunch steppes there are Stipa capillata L., Carex pediformis C.A. Mey., C. duriuscula C.A. Mey., Medicago falcata L., Iris flavissima L., Dianthus versicolor Fisch. ex Link, Lychnis sibirica L., Thalictrum foetidum L., Potentilla acaulis L., P. bifurca L., Goniolimon speciosum (L.) Boiss., Schizonepeta multifida (L.) Briq., Veronica incana L., Galium verum L., Scabiosa ochroleuca L., Artemisia frigida Willd. Among the lichens of low-bunch steppes, the constant species include Cladonia pocillum, Cl. pyxidata (L.) Hoffm., and a constantly migrating fruticose lichen Xanthoparmelia camchadalis (Ach.) Hale. The high species diversity of the low-bunch steppes is complemented with crustose and foliose epilithophytes located on stones. The most frequent crustose epilithophytes are Aspicilia maculate (H. Magn.) Oxner, $A$. transbaicalica Oxner, Lecanora campestris (Schaer.) Hue, L. frustulosa (Dicks.) Ach.,L. crenulata Hook., Candelariella aurella (Hoffm.) Zahlbr., Psorotichia schaereri (A. Massal.) Arnold, Protoparmeliopsis muralis (Schreb.) M. Choisy. The most common foliose species include Xanthoria elegans (Link) Th. Fr., Xanthoparmelia somloënsis (Gyeln.) Hale and Phaephyscia sciastra (Ach.) Moberg. The macromycetes are comprised of Bovista nigrescens Pers, Panaeolus papilionaceus (Bull. ex Fries) Quelet, Amanita vaginata (Bull.) Lam.

The sedge low-bunch steppes are confined to the smooth parts of the lower southexposed slopes, occupying large areas on the plain, including the elevated sites of the river valleys. The main edificator is hardish sedge - Carex duriuscula. Potentilla anserine L., P. multifida L., Artemisia laciniata Willd., Scutellaria scordiifolia Fisch ex Schrank, Iris biglumis Vahl. are often found among the related plants.

The vegetation of stony grasslands or shrubby meadow-steppe is widespread on the tops of bare mountains and southern slopes. In certain places there are thickets of Caragana pygmaea or Spiraea hypericifolia L., S. media, Cotoneaster melanocarpus, Atrophaxis frutescens $\mathrm{L}$.

The low-bunch meadow-steppes are confined to the smooth southern slopes. Among all steppe communities, the low-bunch true steppes are the poorest in species of lichens and fungi. Typical lichen species are Xanthoparmelia camschadalis, X. somloënsis (Gyeln.) Hale, Lecanora frustulosa, Aspicilia cinerea (L.) Körb., Diplotomma venustum Körb., while the typical fungi species comprise Panaeolus campanulatus (Bull. Ex Fries) Quelet. 
Dry meadows occupy the high valley terraces. These meadows include the formations of Calamagrostis epigeios, Trifolium pretense, Sanguisorba officinalis L., Amori arepens, and others [16]. The typical representatives of fungi are Agaricus campestris L., Agrocybe praecox (Pers.) Favod, Scleroderma albidum Pat. \& Trab., and others. Due to the lack of competitiveness, the lichens were not found in the meadows.

In the northeast, southeast, and a small area in the southwest of the town, there is Insky ribbon pine forest [17-18] dominated by scotch pine Pinus silvestris L. Its shrub layer is formed by Caragana pygmea (L.) DC. The herbaceous layer is comprised of Urtica cannabis, Urtica urens L., Fragaria viridis (Duch.) Weston, Onobrychis arenaria (Kit.) DC., Amoria repens (L.) C. Presl, Trifolium pretense L., Convolvulus bicuspidatus Fisch. ex Link, Lamium album L., and others. The soil surface is abundantly covered with the moss carpet of Pleurozium schreberi (Willd.ex Brid.) Mitt., Ptilium crista castrensis (Hedw.) De Not, Rhytidiadelphus triquetrus (Hedw.) Warnst. ,Hylocomium splendens (Hedw.) Bruch et al., Polytrichum sp. The most common species of lichens spread herein include Cladonia gracilis (L.) Willd., Cl. fimbriata (L.) Fr., Cl.coniocraea (Flörke) Spreng., Cl. arbuscula (Wallr.) Flot., Cl. rangiformis Hoffm., Evernia mesomorpha Nyl., Flavoparmelia caperata (L.) Hale, Flavopunctelia soredica (Nyl.) Hale, Hypogymnia physodes (L.) Nyl., H. tubulosa (Schaer.) Hav., Parmelia sulcata Taylor, Peltigera canina (L.) Willd., Physcia aipolia (Ehrh. ex Humb.) Fürnr., Ph. stellaris (L.) Nyl., and others. The most spread species of fungi are Lactarius torminosus Schaeff, L. deliciosus (L.) Gray, Lycoperdon perlatum Pers., L. pyriforme Schaeff, Chalciporus piperatus (Bull.) Bataille, Psilocybe cubensis (Earle) Singer, Psathyrella chondroderma (Berk \& Broome) A.H. Sm., and others. In the southeast (the district of Minusinsk Thermal Power Plant), the stand of Pinus silvestris is often mixed with Betula pendula Roth. The coppice comprises Spiraea chamaedrifolia L., S. media Franz Schmidt, Rosa acicularis Lindl., Caragana arborescens Lam. The herbaceous layer is dominated by Calamagrostis epigeios (L.) Roth, with the abundance of Poa sibirica Roshev., Melica altissima L., Trisetum sibiricum Pupr., Carex macroura Meinsh., Iris ruthenica Ker-Gawl., Trollius asiaticus L., Aquilegia sibirica Lam., Thalictrum minus L., Vicia unijuga A. Br., Rubus saxatilis L., Saussurea amara ( L.) DC., and others. The lichens are represented by the following species: Cladonia botrytes (Hagen) Willd., Cl. carneola (Fr.) Fr., Cl. pocillum (Ach.) Grognot, $\mathrm{Cl}$. coniocraea (Flörke) Spreng., Lecanora symmicta (Ach.) Ach., Parmelia sulcata, Hypogymnia tubulosa, $H$ physodes, Flavoparmelia caperata, Flavopunctelia soredica. Among the macromycetes there are Fomes fomentarius (L.) Fr., Lactarius resimus (Fr.) Fr., L. torminosus Schaeff, $L$. deliciosus (L.) Gray, Leccinum scabrum (Bull.) Gray, Russulavesca Fr., Scleroderma albidum Pat. \& Trab., Clitocybe nebularis (Batsch.) P. Kumm., Cyclocybe aegerita (DC.) Gillet, Coprinopsis atramentaria (Bull.) Redhead. Vilgalys \& Moncalvo, Lycoperdon pyriforme Schaeff, Suillus luteus (L.) Gray, Paxillus involutus (Batsch.) Fr., and others.

The birch and birch-pine forests are situated nearby the village Malaya-Minusa and mostly comprise the meadow and steppe vegetation. Betula pendula, Pinus sylvestris occupy the upper layer, while the lower layer consists of Caragana arborescens, Spiraea media, Cotoneaster melanocarpus Fisch. ex Blytt, Rosa majalis Herrm., Crataegus sanguinea Pall., Padus avium Mill., and others. The lichens and fungi are mainly similar to the species of the pine forests.

There are also poplar coppices along the tributaries of the Yenisei River and in the central part of the town. Tree layer mostly consists of Populus laurifolia Ledeb., while the herbaceous layer is presented by Stellaria graminea L., S. media (L.) Vill., Amoria repens, and others. There are only 2 species of lichens Xanthoria parietina (L.) Th. Fr. and Caloplaca cerina Th. Fr. The fungi species include Pleurotus ostreatus (Jacq.) P. Kumm. and Hemipholiota populnea( Pers.) Bon. 
There are also birch-swampy, birch and willow-birch bluegrass-herb-non-swampy coppices found in the valley of the tributary of the Yenisei River.

\section{Conclusions}

The urban ecosystems are characterized by the specific ecological conditions, where the impact of anthropogenic factor manifests itself to the maximum extent [19]. The urbanization process provokes the significant changes both in vegetation and other components of the natural environment. The natural flora is being replaced by the urban flora with populations of alien plant species. Many species of lichens and fungi are not able to adapt to these conditions and consequently die.

\section{References}

1. Encyclopedia of Krasnoyarsk Krai. South (Krasnoyarsk, 2008)

2. Determinant of plants of the South of Krasnoyarsk Krai (Novosibirsk, 1979)

3. Flora of Siberia, 1-14 (Novosibirsk, 1988-2003)

4. Identification Guide to Lichens of the USSR, 1-5 (Science, Leningrad, 1971-1978)

5. Identification Guide to Lichens of Russia, 6-10 (Science, St. Petersburg, 19962008)

6. Nordic Lichen Flora, 1-6 (Sweden, 1999-2017)

7. S.P. Vasser, Flora of Fungi of Ukraine (Kiev, 1980, 1985)

8. Flora of Fungi of Ukraine (Kiev, 2015)

9. M.A. Bondartseva, Determinant of mushrooms of Russia, 2 (Science, St. Petersburg, 1998)

10. Funga Nordica: agaricoid, boletoid and cyphelloid genera (Copenhagen, 2008)

11. M. Moser, W. Julich, Farbatlas der Basidiomyceten Colour Atlas of Basidiomycetes (1988)

12. M.I. Beglyanova, Flora Agarikovykh of mushrooms of the southern part of Krasnoyarsk Krai, 1-2 (Krasnoyarsk, 1972-1973)

13. M.V. Gorlenko, Mushrooms of the USSR (Moscow, 1980)

14. T.A. Ilyina, Mushrooms atlas determinant (Moscow, 2012)

15. O.A. Vasilieva, Ecology of Southern Siberia and adjacent territories, 18 (1) 2014

16. A.Yu. Korolyuk, N.I. Makunina, Botanical J., 83 (7) (1998)

17. E.S. Smirnova, Ecology of Southern Siberia and adjacent territories, 19(1) (2015)

18. E.S. Smirnova, O.A Zyryanova, Problems of development of agrarian and industrial complex of Sayano-Altai (2015)

19. A.A. Infantov, Messenger of KRASGAU, 10 (2009) 